\title{
Inheritance, Imitation and Genuine Solutions (Institution Building in Hungarian Labour Relations)
}

\author{
CSABA MAKÓ \& ÁGNES SIMONYI
}

A MULTINATIONAL SEEKING IN VAIN A UNION as a counterpart in bargaining; another multinational expelling union representatives from the firm; companies with good and bad labour relations; small and medium-size firms with no unions at all-all these may be found in news items, case-studies and episodes from the near past of labour relations in transformation and development in the post-socialist countries. After five to six years of the political, social and economic transformation can we already speak about a new system in the field of labour relations, or is it still in transformation? Is the experience of this half-decade sufficient to identify the features of the new emerging system with any of the already known patterns of labour relations?

In the late 1980s and early 1990s in Central and Eastern Europe there were widespread illusions as to the prospects of labour relations and the new role of employees and their interest associations. The international, economic and social conditions of the real processes of social transformation in these countries, however, framed events differently, and the new institutions of labour relations and social cooperation seem to display unexpected patterns. Social scientists and politicians as well as unionists are now seeking to understand the real logic of the transformation process and the motives and intentions of the social partners within it. Since the social and economic context of the current transformation process varies from country to country in Eastern and East-Central Europe, very different strategies and practices of institution building, combined with national and local traditions of interest representation and participation, are creating a rich variety of new autonomous systems of labour relations. Several elements of the political and economic transformation are closely connected to the shaping of the labour relations system in the post-socialist countries. Some of them are supporting its development, while others are unfavourable to its strengthening. Certain factors are unique in the different Central and East European countries, others represent international trends. This article aims to illustrate the characteristics of institution building in the field of labour relations in Hungary.

In Hungary the new democratic political order, its laws and institutions, has finally ensured the existence of an autonomous labour relations system after a long period of reforms since the late 1960 s aiming at loosening the subordination of labour relations to a monolithic political order. The political transformation was carried out by social actors and organisations that - even if newly created in democratic processes-were 
related to the practice of the former, gradually reformed system. Experience, traditions, social relations and networks accumulated from the 1970s onward can be found behind the peaceful character of the political and economic transformation in Hungary, and the same factors can explain the continuity of certain practices in the field of interest representation and bargaining as well as the survival of mistrust by different social and political actors towards the institutions of the labour relations system.

\section{Actors and institutions of labour relations in Hungary}

The actors and institutions of labour relations were created in the very complex process of transformation to a market economy, to pluralist parliamentary democracy, and to privatisation of public property through intensive legislation since 1988 in Hungary (Transformation of Public Enterprises-1988, Strike Law-1989, Employment Law-1991, new Labour Code-1992, Bankruptcy Law-1992, Law on Privatisation-1992, Social Act-1993). went (above lode (2011)

The laws on the transformation of former state-owned enterprises into limited liability or joint-stock companies, as well as the law on privatisation, created employers as an independent social and economic actor (le patronat). As the economic transformation and privatisation is a rather complex process consisting of the transformation of state-owned enterprises and the creation of private enterprises through investment by foreign companies as well as the emerging national bourgeoisie, the employers do not form a homogeneous group. Their stratification and the interrelations of their representative organisations in turn exert their influence on Hungarian labour relations.

As to the other social partner, the new labour legislation protects the right of free employee association and the right of trade unions. The new political system and labour legislation transformed the unified monolithic structure of unionism into a pluralist one. In Hungary new independent unions were formed since 1987-88, mostly in the academic community, but in a few larger enterprises as well. These new unions at the beginning took a strong political role, opposing the still existing party-state and the monopoly of the former unions. These latter, however, were already starting their transformation into federalist, more democratic structures and had broken their dependence on the Communist Party.

The other laws on employment, on strikes and the Labour Code set up the rules of negotiations and the solutions of labour conflicts. On the one hand, the new legislation is favourable for the employees as it guarantees union rights and representation and institutionalises collective action. On the other hand, employment is not protected any longer. Rationalisation and restructuring of firms, together with privatisation, are considered more important political and economic targets that are not compatible with the political commitment to full employment, with the former constitutionally guaranteed right to work. Labour lawyers critical of new legislation called attention to the fact that 'social and economic issues have been included in the constitution in a much less considered and elaborate way than the political ones...labour issues were considered as side issues by the leading political forces of transition' (Kollonay \& Ladó, 1992, p. 23). 
The liberal ideology of economic deregulation and social transformation, the moves towards a free market economy and the new emerging private employers are often opposed to the strong influence of the trade unions. At the same time, however, the new political system needed social institutions to legitimate the transformation, for the stabilisation of society, for the control of social conflicts and to negotiate about the social costs of the fundamental changes. (In 1990, when the Hungarian capital was paralysed by a blockage of taxi and truck drivers protesting against the radical rise of fuel prices, the conflict was negotiated and settled within the National Council for the Reconciliation of Interests (NCRI) established already in 1988. This was the first time after the political turn that an institution of labour relations demonstrated its social and political utility for the new political forces through its capacity to deliver a nationwide agreement.)

\section{Actors and strategies}

The new social partners and their strategies have been undergoing significant changes since the beginning of the transformation.

The state remained the most important actor in the field of labour relations by its role as employer and by its political role. By this latter role the state is responsible

- for labour legislation and for supervision of its implementation,

- for the creation and maintenance of employment services,

- for participation in tripartite negotiations with the trade union confederations and employers associations. This tripartite body, already created before the political transformation, aimed at developing social dialogue and sharing the responsibility for decisions in the worsening economic conditions of the 1980s. The tripartite national-level negotiations in the NCRI later helped to work out and stabilise the basic rules, principles and standard regulations of Hungarian labour relations.

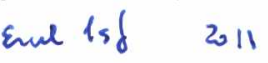

The state, through its intervention in economic processes like investment, privatisation and monetary policy, has a decisive influence on the labour market, on employment and working conditions. Since 1993 in Hungary wage policy has not been centralised and wages are open to agreement between employees and employers. Only minimum wages are settled by joint agreements in the National Council for Reconciliation of Interests. However, the state has no means to ensure that these agreements are respected.

As employer the state owns a gradually diminishing number of firms in the economy, so the number of employees in public firms is decreasing. More than half of employment is already in the private sector. (Estimation of such sectoral distribution of employment is rather difficult owing to the large proportion of mixed property.) The state still is the largest employer and its role is especially important in the largest industrial firms, in public administration, transport, finance, education, health and other social services.

In the branches where the state is the main or only employer the trade unions are traditionally strongest. Consequently, in these fields the state as employer is under strong union pressure. In Hungary, where strike activity remained rather low compared with the other Central East European countries, the most important strikes were 
TABLE 1

Strikes In Hungary and POLAND

\begin{tabular}{lrrrrrrrr}
\hline & \multicolumn{3}{c}{ Number of strikes } & & \multicolumn{3}{c}{$\begin{array}{c}\text { Number of participants } \\
\text { (in thousands) }\end{array}$} \\
\cline { 2 - 3 } \cline { 6 - 8 } & 1991 & 1992 & 1993 & & 1991 & 1992 & 1993 \\
\hline $\begin{array}{l}\text { Hungary } \\
\text { Poland }\end{array}$ & 3 & 10 & 17 & & 250 & $25-30$ & 20 \\
\hline
\end{tabular}

Source: 'Ha már elhallgat a csend', Heti Világgazdaság, 24 February 1994.

organised in the state-owned branches like rail transport, the energy sector and education (Table 1). (Even in the police and the military the government as employer has been threatened by the respective trade unions with warning strikes.)

The representation of employees within the system of labour relations is undergoing significant changes. Its polarised character has become consolidated, although immediately after the political turn the trade union movement had a fragmented character, a great number of smaller and larger new unions and federations were formed, and their relations were rather conflictual. At national level the main aims of rivalries were for political influence and redistribution of the former unions' huge assets. A slow crystallisation and concentration of the trade union movement reduced the number of union confederations to the following six by 1993 :

- MSZOSZ (National Association of Hungarian Trade Unions), the successor to the former unified trade union, which in its present form of organisation as a federation of branch unions has existed since 1988.

- ASZOK (Confederation of Autonomous Trade Unions), the successor to a few influential former branch unions like those in the chemical, pharmaceutical and a part of the railway sectors.

- LIGA (Democratic League of Independent Trade Unions), the first genuinely independent union confederation born as part of the political opposition to the party-state at the end of the 1980s.

- MOSZ (National Alliance of Workers Councils), another new and independent trade union centre, created in certain industrial plants by skilled and militant workers with a strong nostalgia for the self-governing bodies of industrial organisations.

- SZEF (Cooperation Forum of Trade Unions), the most influential branch organisation in public administration and in the service sector.

- ESZT (Intellectual Workers Trade Union Association), a relatively small union centre comprising some organisations in education and research.

In the new conditions almost all union centres were facing internal and external legitimacy problems at the beginning of the 1990s. The almost $100 \%$ membership of employees in unions in the period after World War II has diminished to ca. $30 \%$ in most of the Central East European countries. This rate can still be considered high in comparison with the most developed industrial (OECD) countries. In Hungary the average membership of all the union centres seems to be stabilised around one-third 
of the active wage-earners. This radical decrease in union density rate can be explained by several factors:

- Employment has been reduced dramatically; more than one-third of the jobs existing in the late 1980s were destroyed in the few years of the "transformation crisis'. Inactivity and unemployment are radically reducing the possible social space for traditional union activities.

- The manufacturing sectors as core fields for union activities are losing importance in employment.

- The decentralisation of the organisational structure of the economy has also had an impact on the sphere open to unions. The proportion of micro organisations and family enterprises without unions has increased substantially in a very few years. In the 1980 s only $4-5 \%$ of active wage earners worked in individual or family business organisations. In 1993 this had increased to 21\% (Laky, 1994, p. 74).

- The increased political and ideological rivalry at the beginning of the 1990s among the trade union confederations disillusioned and alienated employees. On the firm level one-time and possible members of the unions were less interested in this rivalry and often missed the appropriate union support in the everyday problems related to privatisation, restructuring and the reduction of employment.

- The deep cuts in the social infrastructure of firms, run by the unions, diminished the advantages of union membership.

- The spread of new managerial techniques and the implementation of the 'leading edge' practice of Human Resource Management (especially at the multinational companies) opened direct dialogue — without union presence-between employers and rank-and-file people. Individual working contracts have also weakened the influence of unions on interest representation.

The successor union centres-mainly MSZOSZ - were under strong political pressure not only from the newly emerging autonomous unions but also from the new political and government forces. Their credibility as autonomous new organisations to represent employee interests was questioned at different political forums-even by parliamentary forces-because of their former subordinated role to the communist party. This political rivalry on the national level, seeking political legitimacy, often distracted the forces of the federation from employment-related issues. MSZOSZ lost a considerable part of its membership owing to the pluralisation and transformation of labour relations, but it continued to have the largest number of members.

The new autonomous trade unions born in the political battles of the late 1980s faced a different type of legitimacy deficiency. They had no organisational roots in the world of work, which was reflected in the low level of membership. This has placed a questionmark against their representativeness vis-à-vis government during national-level consultations. After the establishment of the new political institutions of pluralist political democracy, these unions were forced to learn the "profession of unionism' and to leave the political arena to the new parties. (Many activists have left the new unions and become important figures in the new political parties.)

After the political transformation, the representativeness of the trade unions was tested several times. These tests were decisive even for the redistribution of trade union assets (i.e. real estate, companies, publishing houses, schools, resorts 
and sports centres). As the union confederations could not settle the conflict about distribution of union assets among themselves, the government took the initiative. Union members were required to renew their membership in 1992 if they wished it to continue. The result of this test did not modify the membership distribution and MSZOSZ maintained its majority.

The second test was organised together with the elections for self-governing bodies of the Health and Pension Insurance schemes. In Hungary these two big social security funds have been run by tripartite bodies since 1993. Employees are represented by delegates of the unions in the six union centres. Their first election was organised together with the first Works Council elections. The results of these elections were expected to be the guidelines for the provisional redistribution of union assets (for the detailed result see the Appendix). MSZOSZ reinforced its political and organisational legitimacy during these elections. It obtained $72 \%$ in the Works Council elections, $50 \%$ of the seats on the employees' side of the Pension Insurance Body and 45\% of the employees' side in the Health Insurance Body. In 1995 the second Works Council elections only slightly modified the above proportions, which remained the definitive ratio for redistributing the former union assets.

The successful transformation of the former unions could be explained by several factors:

- they maintained their administrative and economy-wide organisational network,

- they had more tradition, practice and skill in the field of negotiation on the national as well as on the firm level,

- the new trade unions from the beginning have adopted a more conflictual strategy to fight the economic power of management of the former state-owned companies and later in the privatised firms, while the former unions, following their traditions, were more cooperative with management, putting more emphasis on the survival of the firm,

- the conflictual strategy of the new unions did not fit with the privatisation intentions of the new political forces (which not so long before were founded and supported by the same new autonomous unions).

After the stabilisation of membership rates and the results of the repeated tests of legitimacy, the settlement of the redistribution of trade union assets seemingly cooled down the rivalry. The tendency to fragmentation has stopped and a new period of concentrating union efforts seems to have opened. This is expressed by increased coordination between different union centres at national-level tripartite negotiations, and there are intentions of unification on the part of the smaller union centres. Two influential centres, MSZOSZ and SZEF, have concluded a strategic alliance to coordinate their actions.

The employers as social partners are composed of very different groups, different in their social background, in economic weight, in their political influence and in their labour relations strategies. One important group of employers is formed by the managers of the remaining state-owned firms. The new entrepreneurs might be Hungarians or foreigners, buyers of once state-owned firms or smaller units, or even owners of newly established companies. They formed organisations according to the dimensions of their firms or according to the origin of their capital. Small 
entrepreneurs and artisans have set up their own traditional associations. Multinational firms constitute another small but rather influential group of employers.

In the National Council for the Reconciliation of Interests, the employers' side is constituted by nine organisations:

- MGYOSZ (Manufacturers National Association), which concentrates Hungarian proprietors of larger firms and some of the foreign-owned firms,

- MMSZ (Association of Hungarian Employers), which is the organisation of employers of public and mixed firms,

- VOSZ (National Association of Entrepreneurs) is the association of small and medium-size firms,

- Hungarian Industrialists' Federation,

- IPOSZ (Industrial Craftsmen Association), both representing artisans,

- Agrarian Employers Association,

- MOSZ (National Federation of Agricultural Producers and Cooperatives),

- AFEOSZ (National Federation of General Consumers Cooperatives),

- KISOSZ (National Federation of Retail Traders).

The multinationals have formed their own pressure group, a special association. It is not a participating member at the National Council for Interest Reconciliation but regularly meets key ministers and decision makers of the government.

Among the social partners the employers form the most heterogeneous side. Their interests, as well as their political influence, differ considerably according to the sector and dimensions of their firms. The unfinished privatisation is still keeping the employers' side in a fluid state. Their fragmented associations have fewer roots and traditions than the union side has. Lacking coordination and similar or joint interests, they were regarded as the weakest social partners at the tripartite negotiations. Only recently were intentions of more coordination among them identified. The two largest associations, MGYOSZ and MMSZ, have agreed to cooperate more closely for more efficient representation of employers' interests at national-level negotiations.

As to the strategies of the different employer groups in the field of labour relations, they are far from being homogeneous. The proprietors of small and medium-size enterprises are rather conservative and anti-unionist. They oppose the intervention of the state in employment relations. In many of the small and medium-size firms even minimum wage levels fixed at the national tripartite negotiations are not implemented. A great part of 'black labour', without legal regulations and guarantees, is employed in this sphere.

Employers and managers in the large plants already have the tradition of dialogue with the trade unions and of direct negotiations with the employees. In these firms (privatised completely or partially or still in state ownership) management is interested in maintaining consensus and cooperation with the unions. In certain cases in the remaining state-owned organisations management and unions have a common interest in obtaining more subventions, credits and investment from the government. (For example, the rather strong and annual strike activity at the National Railway Company-organised jointly by three different unions of the branch-represents pressure on the government to finance wage increases and technological development.) 
Multinational companies, which might have come to Hungary by buying completely or partially state-owned firms or by 'green-field' investments, follow their own model of labour relations. This might be in certain cases anti-unionist, in others favourable to 'micro-corporatist structures' of firm-level communication and negotiation without the branch unions. The practice of labour relations in the Hungarian plants of these multinational companies is regarded as an international challenge by unions. The branch union in the chemical sector, for example, has already initiated international cooperation with the unions of the home countries of the different multinationals to establish common standards for collective bargaining with the international management (on the different approach of multinational companies to labour relations see the Appendix).

\section{Legal regulations and institutions}

The most important source of labour legislation is the new Labour Code adopted by the freely elected Parliament in 1992. It completed the cumulative changes in the system of labour relations and set down the legal framework for its key institutions:

- It legitimates the national-level institutions of interest conciliation (the NCRI, established in 1988).

- It lays down the rights and conditions of union activities in firms.

- It defines the representativeness of the unions within the circumstances of the pluralistic union movement.

- It regulates the conditions of collective bargaining and labour disputes.

- It establishes the institutions of Works Councils as a tool of employee participation and describes the conditions of their creation and their functions.

In this section we shall focus attention on collective bargaining and Works Councils as key institutions of Hungarian labour relations.

Although collective agreements existed both on branch and firm level even before, collective bargaining had very limited meaning owing to the lack of autonomy and independence of the partners. The party-state regulated what should be settled in the collective agreements and the lack of autonomous partners made the bargaining process fictitious.

To analyse the specific features of collective bargaining in Hungary we distinguish two different types, both of which are playing an important role to reach a degree of consensus and some form of more or less conflictual cooperation. The traditional and well known decision-making process created and maintained by the social partners of industrial relations in the field of employment-related issues (i.e. wages, working conditions, etc.) can be considered as the first type of collective bargaining. The second type is providing an institutional tool to build consensus on the principal orientations of the social and economic policy of the country. In Hungarian practice the National Council for the Reconciliation of Interests as a tripartite body illustrates well this extended type of collective bargaining.

The new Labour Code has created a legal framework within which free bargaining can be possible between employers and employees. Fundamental changes characterise the content and the partners of collective bargaining. As to the content, the Labour 
Code sets a statutory minimum of employment conditions - collective agreements could provide more favourable conditions. The Labour Code recognises the trade unions' right to sign collective agreements at national, branch and firm levels. At one employer one collective agreement can be concluded. If there is only one union at a given employer to sign this agreement on the employees' side it should get more than $50 \%$ of the votes during Works Council elections. According to the Labour Code, a collective agreement might be signed by several unions at the same firm, presupposing that they have a common platform and obtained together more than $50 \%$ of the votes during Works Council elections. Unions having less than $10 \%$ at Works Council elections are not considered to be 'representative' negotiating partners. Employers at firm level should annually put a draft collective agreement to the local one or more representative unions and this draft should include at least provisions on wages.

The role and influence of collective agreements are somewhat difficult to evaluate, for several reasons. First, in the current unfavourable economic situation-after a deep recession since 1989 and amidst the high foreign and internal debts of the government-the partners have limited scope for action. Second, neither the employers nor the unions have accumulated the necessary experience for on-going bargaining. Third, successful bargaining would require the identification of the partners, which has not yet been completed among employers on the national and branch levels, mostly because the process of privatisation is not yet finished.

Managerial interests in agreements and in their contents might differ before and after privatisation and even according to the possible perspectives of privatisationwhether the firm is to be sold in different parts or as a whole, who are the expected new proprietors, whether management and/or employees might have a share in ownership of the future company, etc. These are all open questions that might influence most of the issues on the agenda during collective bargaining but may be beyond the influence of the bargaining parties.

Other important dimensions are the levels and coverage rate of collective bargaining. According to international experience (or at least the existing patterns of the OECD countries) the coverage rate of collective agreements concluded is generally higher than the average union density rate (Traxler, 1994). As we have no statistics on the number of employees covered by accepted collective agreements we rely on estimates. In Hungary the norms and procedural dimensions for branch and firm-level bargaining are set at national level in the Council for the Reconciliation of Interests. This tripartite organ conducts the extended type of national level collective bargaining in which the social partners are consulted on macroeconomic strategies, social policy packages, taxation or the annual budget. The consultations are carried out at plenary sessions among representatives of the three social partners. The Council has special subcommittees to negotiate on different issues of employment, social policy, budgetary issues etc. The members of the unions' and employers' sides also have separate sessions to prepare their stand for the plenary sessions. The Council itself has a small administration for organising the consultations and communication between the social partners.

Evaluating the forms and levels of collective bargaining, we could say that economy-wide, branch (or meso) and firm-level collective bargaining are simul- 
taneously present in Hungarian labour relations practice (see Appendix Table A.6). Therefore it is impossible to use a general coverage rate. According to the summary of the Phare Fact-Finding Committee the following coverage rates could reflect the influence of collective negotiations (Ladó \& Tóth, 1995):

- Economy-wide agreements set the level of minimum wages in Hungary for the whole community of wage earners. (Since the establishment of the National Council for the Reconciliation of Interests minimum wages were increased considerably, even if they could not keep up with rising prices and costs of living; see the Appendix.) Evaluating the performance of the plenary sessions of NCRI, these macro-level consultations might be said to have been dominated by issues concerning socio-economic policy: more than $50 \%$ of the items discussed belonged in this category. Questions of wages, working and employment conditions represented only $20 \%$ of the items, while vocational training policy accounted for $10 \%$ of the items discussed at plenary meetings.

- Sectoral bargaining-or meso-level negotiations-were estimated to cover only $11 \%$ of employees, in 12 agreements.

- Firm/establishment level-or single-employer-bargaining is considered to be by far the dominant tendency in Hungary; $30-35 \%$ of the firms are covered by this level of collective bargaining in the competitive branches of the economy. This means that the number of employees covered by collective bargaining may be even higher.

Apart from the levels and coverage of collective bargaining it is worth noting the changes in the topics of labour disputes between employers and employees at firm level. Nowadays, besides the still important question of wages, we find privatisation, reorganisation of the firms and, connected to these issues, the problem of employment protection. Circumstances and procedures of redundancy have also moved into the centre of labour disputes (Table 2).

Concerning the atmosphere of collective bargaining, the current feature of labour relations in Hungary is the cooperative approach between unions and management. To

TABLE 2

Changing Topics of Labour Disputes

\begin{tabular}{lcc}
\hline Subjects & Before 1990 & 1990 and after \\
\hline Reorganisation of the company & 96 & 117 \\
Implementation of privatisation & 30 & 114 \\
Introduction of workers' ownership & 24 & 109 \\
Safety in the workplace & 85 & 175 \\
Wage issues & 245 & 213 \\
Other allowances & 196 & 158 \\
Work schedule and shift work & 84 & 54 \\
Work time (overtime) & 84 & 64 \\
Redundancy payments & 39 & 122 \\
\hline
\end{tabular}

Source: Makó \& Novoszáth (1995, p. 261).

Labour relations officials were interviewed in a national sample of 345 firms. The numbers express how often the above issues were mentioned as topics of disputes in these firms. 
strengthen the cooperative patterns among the social partners a new institution of labour relations was set up in the summer of 1996; the National Service for Reconciliation and Arbitration was founded to settle labour disputes in their very early phase and at their site of origin.

This cooperative approach was not questioned even in cases of major cuts in the workforce and massive lay-offs. According to a survey by the Japanese Institute of Labour carried out in a large sample of Hungarian firms the majority of firm-level unions (99) have accepted and a significant number (64) have even supported cutbacks in employment. Only 20 local unions have declared their rejection of lay-offs at their plants (JIL, 1992). No differences were found in this approach backing the reduction of employment between unions belonging to the different centres and confederations.

Another new key institution of Hungarian labour relations is the Works Councils. This represents a radical break with the past, when trade unions' functions of representing employee interests and employee participation in managerial decisions were confused. The new Labour Code separates the main function of the unions, that is interest representation, participation in collective bargaining and organisation of collective action, from the participation of employees. 'Participatory rights are exercised in the employees' name by the Works Council or work delegates elected by them' (Labour Code, 1992, ch. IV, Para. 42).

Works Councils have to be elected at every work place where the number of employees is above 50 by secret ballot from among the candidates nominated by unions or other groups of employees. (In smaller organisations, but with more than 15 employees, work delegates should be elected.) The Works Councils (and delegates) are elected for a three-year period and are aimed at developing social norms and rules for long-term conflict solution. They have three types of rights:

(1) To give and refuse consent to the allocation of the social welfare funds and the utilisation of social facilities and real estate of their firms specified in the collective agreements. Beside this type of joint decisions an agreement has to be reached between management and the Works Council on labour health and safety regulations too.

(2) To be informed of and asked to comment on a broad range of issues (i.e. drafts of measures that have an impact on a large segment of employees, like the reorganisation of the firm, privatisation, mergers, vocational training, career development, etc.).

(3) The employer has the obligation to inform the Works Councils at least every six months about the principal factors affecting business, trends in employment and in wages, major decisions concerning production and investment.

These participatory rights of the Works Councils are regarded as more limited than the earlier participatory rights of the former unions, namely the rights of the shop stewards' bodies in the 1970s and 1980s. In the early 1990s there was a fear that such rights would interfere with 'free bargaining' and would conflict with the rights of the emerging private owners and employers. 
The rights-including co-decisions, consultations and information-of the Body of Shop Stewards in reality were equal to the strong institution of workers' participation in West European Countries (i.e. German Works Councils). In this perspective, the rights of shop stewards could have been transferred to rights of the new Works Councils without creating serious problems for the emerging market economy and private employers. But the new labour regulation did curtail considerable the participation rights of trade unions - and in general the rights of trade unions - and the Body of Shop Stewards was replaced by the institution of limited participation-in the framework of the Works Council-of the employees. (Hethy, 1995a, pp. 4-5)

Even the initial intentions of legislators to separate the representative functions of trade unions from direct employee participation (similarly to the German model) were not completely successful. Owing to the several tests of legitimacy and to the obligation to redistribute former union assets according to the results of the Works Council elections, trade unions were forced to 'occupy' these institutions. We do not yet have enough experience to judge how well delegates in the Works Council can separate their participation from the bargaining activity of their unions.

\section{Participation as a characteristic feature of Hungarian labour relations}

The various components and institutions of the Hungarian labour relations system have developed unevenly over the past decades. None of the three areas-creation of national-level tripartite or bipartite negotiations, institutionalisation of collective bargaining, and labour disputes-were tolerated in the logic of the monolithic political system that lasted until the end of the 1980s. While there always existed the need to create social consent at workplace level that favoured the development of various forms of employees' participation in Hungary, the motives were very different, ranging from management's interest in cooperation with rank and file people, the adaptation and spread of new managerial techniques, to the ideologically motivated aims of workplace humanisation with special emphasis on identification with the firm, or to the politically motivated attempts to introduce so-called selfmanagement schemes to counterbalance the growing managerial power. (These last-mentioned intentions were especially visible in the 1980s, designed to keep political control over the emerging technocrats, local or branch level union bureaucracies often in coalition with managers of the firms, who succeeded in influencing the redistribution processes in directions contrary to the efforts of the national political actors.) The concepts to implement these counterbalancing solutions and the life-span of the different participation schemes were objects of interplay between different social forces on firm and national level.

Both forms of employee participation, direct and representative (indirect), were widespread in Hungarian practice. The most important direct forms were in experiments with autonomous working units, group-level decisions on wage distribution, group-based cost-reduction centres, internal subcontracting systems, and especially in the widespread and highly publicised economic working associations (VGMK) of the 1980s. The growing role of union representation, expressed in the different shop steward and firm-level union committee rights since the middle of the 1970s, together with the creation of the Enterprise Councils as self-governing bodies in the second 
half of the 1980s, was the most significant development of indirect participation. The unions, having gradually obtained their participating and bargaining rights, were anxious when they saw other direct forms of employee participation and non-union representation being initiated. They were afraid of losing their newly acquired functions (of the 1970s) in employee representation, which was a well known phenomenon of the labour relations systems in the industrialised countries. In Hungary their position was more troublesome as they were still in a politically dependent position till 1989 and they felt threatened more by non-union controlled representation and direct participatory forms or new managerial techniques to create direct communication with employees.

Research shows that in Hungary employee participation has been a key element of labour relations since the 1970s. In its different forms, it partially replaced the autonomous institution of collective bargaining and labour disputes and, together with informal mechanisms of interest conciliation, contributed to the stability and flexibility of the labour process and created a lasting practice of cooperation between the partners at firm level (Ishikawa, 1992). The tight labour market situation and organisational problems generated by the shortage economy strengthened the informal power of certain working groups playing a key role in solving them. The enlarged possibilities of participation at firm level since the 1970s helped certain employee groups to accumulate important social skills in evaluating and manipulating social and organisational situations, in negotiating with different social partners and in elaborating overall views of the enterprises and their environment. The same experience called attention to the limits of participation and showed which missing elements of the labour relations system hindered the wider and more efficient use of firm-level participatory schemes.

Since 1988-89 the innovations of the renewed autonomous labour relations system became especially important in the situation of sweeping changes in the Hungarian economy, when property relations went through a comprehensive transformation, public firms were privatised and a new private sector developed, decentralisation of former large organisations was carried out, and a deep economic recession damaged almost all spheres of the economy. In the circumstances of these unstable economic conditions and the huge social costs of transformation paid by large groups, the new elements of labour relations helped to maintain stability and sometimes even to resolve critical situations of unrest.

At first glance, after the transformation, participation on the firm level seemed to lose its importance. Some observers expected (and still expect) the importance of firm-level negotiations and bargaining (in formal or informal ways) to diminish under the pressure of the new phenomenon of high unemployment. Others expect that private property and capitalist management will 'import' the well known managerial methods and techniques of firm-level negotiations for 'manufacturing consent' (Poór, 1994).

Apart from these assumptions-which we shall attempt to refute later-the place of participation in the Hungarian labour relations system has certainly changed. First of all, it has lost its political and ideological significance-local employer-employee conflicts can hardly be transposed into basic social contradictions. Its functions connected to firm-level issues became more circumscribed. Meanwhile the social and 
political positions of the partners were altered at firm level by the appearance of direct private property, the definite disappearance of the 'mythologies' of work and the 'class approach', the declining production because of the deepening recession, and the new institutions and legal possibilities to influence decisions or protest at firm level. It would, however, over-simplify the situation to conclude that new rights were acquired by employees in a historical period when they lost their real bargaining strength under the pressure of the labour market and the recession.

Employee groups in a strong position within firms can still be found, despite dismissals and unemployment. Even with increased unemployment, productivity declined until 1993, demonstrating the survival of low work requirements. The high social costs of transformation and the lowering of living standards have been tolerated without major political unrest and the strike rate has been low in the past few years. Some strikes have been desperate revolts against 'non-cooperative' management of workers in marginal sectors and positions, while others have been mounted by powerful employee groups in order to improve their pay and working conditions.

A view widely accepted among labour relations experts is that, in periods of recession, when unemployment increases, the number of strikes diminishes. This is taken to be a sign of the weak bargaining positions of employees and their unions. In this respect, Hungary seems to be no exception. While in the 1980s there were widespread fears among Hungarian (and other Central and East European) political and social scientists that a fall in living standards accompanied by a retreat from full employment would lead to social unrest, this has not been the case in these first years of the transformation. Unemployment, never known after World War II, rose to a rate of $14-15 \%$ in 1993 and then diminished slightly to the present $12-13 \%$. The number of strikes and their participants, despite a considerable increase in 1995, have remained low in Hungary, thereby testifying to the validity of the above 'rule' on the lower level of open and manifest conflict attributable to the weakened bargaining positions of workers still in employment. In Hungary, where the majority of the jobless are long-term unemployed and hundreds of thousands are in casual employment, those who managed to keep their jobs in the first waves of lay-offs and workplace closures are considered necessary for the stabilisation and possible recovery of their firms.

In several case studies (Makó \& Simonyi, 1995) one can find very different experiences concerning direct participation and informal bargaining of employees, according to the various organisational and managerial settings. In a large steel plant, for example, where collective bargaining was less successful for the employees, they withdrew from participation in problem solving and quality control. But in the declining textile sector we found a case where workers who were engaged in very conflictual strikes in the same period regularly participated in solving the technological and organisational difficulties of their plant. Participation may express deep and long-term interests of the employees in the survival of their firms even in times of labour disputes, but it may not replace successful collective bargaining. In Hungarian labour relations practice the institution of participation used to be and seems to remain a possibility for the social partners to express their intentions, to communicate, to revise and prepare collective bargaining or to prevent collective disputes. It used to and continues to offer a certain flexibility to the system of labour relations. 
As a new element of the transformed Hungarian labour relations we have already mentioned the Work's Councils as institutions representing all employees of a workplace. Their predecessors have appeared in several different revolutionary periods in Hungary, in 1918-19, between 1945 and 1948, in 1956, as institutions to ensure workers' control while management's influence has been weakened. Despite obvious differences in social, economic and historical circumstances there are several common institutional features in their reappearance and functioning:

(1) Workers' councils were created in revolutionary situations when traditional institutions of political democracy were paralysed and radical changes in property relations created a vacuum and instability in management.

(2) This form of workers' self management aimed to integrate the contradictory roles of employers and employees. It sought to defend the interest of employees (like any classical union) and take over management's responsibility too in organising production. In 1919 for example, workers' councils had to deal with keeping labour discipline, defending the socialised form of property and controlling production.

(3) These councils never limited their activities to the firm level, but sought to establish ties both horizontally and vertically, with the ambition of gaining political control over the country's economy-partly because of their political ambitions but also to stabilise new political, social and managerial institutions (Varga, 1990; Szalai, 1995).

The present Works Councils were not created with these ambitious aims. Besides participation in interest representation and bargaining through the unions, the present form of Works Council can be regarded as an institution for employee participation. Their mandatory system has certain similarities to countries (like Germany or Austria) with a so-called dual system of labour relations. Works Councils are expected to develop social norms and rules of the game for long-term conflict resolution among the social partners at firm level. The outcome of these rules might foster or enhance cooperation between employers and employees and among their different groups.

Mention should finally be made of a new emerging element of employee participation as a social product of spreading innovative managerial techniques in the field of human resource management (HRM). In the vacuum of labour relations immediately after the political transformation the need for everyday communication and problem solving placed a particular value on direct relations between managerial and employees' groups. Beside that, the transfer of Western managerial skills and systems is one of the most visible and urgent challenges for the Hungarian economic elite owing to the growing influence of Western and multinational firms. Spreading forms of teamwork, 'lean' and 'flatter' organisations with reduced numbers of hierarchical levels, establishing more 'heterarchic relations' within organisations, reorganisation of firms' newspapers and bulletins, and group discussions are all on the list of new managerial initiatives.

Privatisation, production decentralisation, the crisis of the redistribution mechanisms, the narrowing possibilities of 'concession policy', the pluralisation of employee and employer organisations separately and together constitute the challenge for labour relations. Not by chance have the social partners been urging a 'social pact' 
since 1990. The aborted attempt in 1995-in our interpretation-is revealing as to the present state of labour relations: on the national level the political framework of labour relations and the position of the main actors seem to be stabilised, while on the firm level labour relations are shaped by forces following different rationalities of their own very diversified product, capital and labour markets as well as the different cultural patterns of their everyday actions. These two tendencies of the mid-1990s made the pact unnecessary and superfluous.

Apart from the outcome of this attempt to create the social pact, from time to time one can witness at national level the need to stabilise social relations through centralised agreements. But at firm level, despite the relatively high unemployment rate and economic recession, high quality performance, problem solving and adaptivity cannot be obtained only through central agreements. Cooperation between employers and different employee groups is based on economically motivated collaboration and not on institutionalised and/or ideologically motivated social obligations. That leads, even without public intervention, to 'micro-cooperativism' (Streeck, 1988) constituted by the rational self-interest of the social partners concerning employment, wages, qualifications and working conditions. When, on the managerial side, quality, adaptivity and problem solving, and on the other side employee interests related to working conditions and prospects are achieved, these results may distinguish cooperativism from passivity attributable to weak bargaining positions. This tendency, described in the highly developed countries in the past decade, can be identified in some dynamic spheres of the Hungarian economy as well. Thus, within the system of labour relations very heterogeneous firm-level configurations as a consequence of the multiform presence of participation are acquiring decisive importance. The unified central patterns of labour relations are important in setting a stabilised political background and norms for the relationship of the social partners, but their role in orienting firm-level labour relations should not be overestimated.

\section{Summary}

At the present state of developments we would refrain from classifying the Hungarian system with any of the existing labour relations models (like corporative or antagonistic, centralised or decentralised, Northern or Southern, European versus Asian, etc.) But we would like to take over a few categories from the international literature to characterise the approach and the strategies of the social partners as well as the structure and functioning of the emerging Hungarian labour relations.

(1) With the present property and organisational structure of the economy the national-level tripartite negotiations gained special importance. This sort of centralisation of negotiations between the social partners has been based on the already existing, however limited, mechanisms of national-level interest conciliation. The practice of national-level tripartism proved to be advantageous during the politically and socially conflictual period of the transformation. But the centralised character of that very visible institution of labour relations cannot be generalised for the whole system. The property relations and the dimensions of economic organisations are far more heterogeneous, and closer analysis of labour 
relations in their everyday practice reveals diversified mechanisms and solutions in employment relations. The relatively low coverage rate of collective bargaining on branch and firm levels illustrates well the limited impact of the centralised negotiations, especially in work and employment-related issues.

(2) In our analysis we attributed special importance to employee participation in all forms, in its legal institutions, in informal ways and within the techniques of Human Resource Management. With the creation of the Works Councils-even if they have at present limited rights-labour legislation created a dual structure of labour relations. Within this dual structure trade unions are actors in representing employee interests, while employees can become partners in firm-level decision making in the Works Councils. Collective bargaining and collective actions organised by the unions are tools to ensure cooperation and to solve conflicts from time to time in the short run, while the various forms of employee participation set down the rules and patterns of lasting cooperation between the social partners. The Labour Code, by the creation of the Works Council, gave an institutional framework to this later ambition.

(3) This present period of transformation has led to rather controversial observations concerning employment relations. Even in a worsening situation on the labour market the bargaining power of certain employee groups has increased. In spite of the high social costs of restructuring, the level of conflictuality remained relatively low. Even at a time of national-level disputes between the social partners on macroeconomic issues, on the firm level unions are working together with management to solve organisational, employment or human consequences of the transformation. A longitudinal study on the identification of employees with unions and with management in the very competitive electronic and electrical industries revealed quite close levels of loyalty to both categories of actors at firm level, a phenomenon called 'double loyalty' (Makó \& Novoszàth, 1996). But the national-level agreements and the firm-level cooperation between the partners do not automatically offer universal coverage for Hungarian labour. The labour relations system is fragmented; unemployed people, employees in small and medium-size firms, the growing number of seasonal and temporary employees, etc., representing a very significant part (if not the majority) of the Hungarian labour force are not under the 'umbrella' of the labour relations system.

(4) The intensified internationalisation of the Hungarian economy since the transformation is leading to various consequences in the system of labour relations. The international trend of the 'decline in the political influence and economic bargaining power of labour due to the mobility of capital and fixity of labour' (Flecker, 1994, p. 93) can be experienced in Hungary too, where the presence of multinational corporations in the manufacturing sector is extremely strong. The so-called greenfield manufacturing accounts for about $15 \%$ of the Hungarian GDP now. To cope with the challenge of globalisation, unions eager to develop new and innovative approaches are in an unfavourable position compared to capital utilising heterogeneous, flexible and individualised forms of employment and capable of high international mobility. The Hungarian unions are now coping with the consequences of restructuring ownership, of organisational and sectoral changes within the context of globalisation. These changes are forcing them to 
shift their attention from seeking external (political-ideological) legitimation to internal legitimation through, for example, stronger campaigns for the acceptance of EU labour standards or by recruiting members from new target groups (like women, part-time employees, young people, service sector employees, etc.).

Hungary, together with the other Central and East European countries, had to face several types of pressure to create or build up social institutions based on different types of social and economic regulations and developed in different historical contexts. After World War II the monolithic model of Soviet-type labour relations had to be adopted without any respect for the useful elements of the pre-war Hungarian system. Following the collapse of the socialist-type political and economic regime and the creation of new institutions in the field of labour relations, many advocates of transformation rejected ideas of possible recombination of any old and new elements. At the beginning of the 1990s we saw a strong wish for 'institutional imitation' even in this field. The importance of participation, the existence of cooperative patterns, the so-called 'double loyalty' were not taken into consideration and were classified as informal elements of a former, not yet autonomous labour relations system. Behind pure theories the everyday practice of labour relations is however more 'opportunistic' in following those patterns that proved to be successful for the interests of the social partners, leading thus to interesting combinations of 'old' and 'new' actors and institutions, new legal regulations and traditions. The outcome of interest conciliation in the long run can definitely legitimate the new actors and institutions of labour relations at national level as well as at the workplace.

Institute for Social Conflict Research, Budapest

Eötvös Lorand University, Budapest

Bibliography

Erzsébet Berki, 'Bérmegállapodások, 1993' (Wage Agreements, 1993), Munkaügyi Szemle (Labour Review), XXXVIII, January 1994.

Dorottya Boda \& László Neumann, 'Employees as New Owners of Privatized Firms in Hungary', XIIth World Congress of Sociology Research, Committee no. 10, Bielefeld, Germany, 18-23 July 1994.

Michael Burawoy \& János Lukács, The Radiant Past (Chicago, The University of Chicago Press, 1992).

Eckhardt J. Dittrich, Csaba Makó, Péter Novoszáth \& Frank Rudolf, Corporate Culture in Transition to the Market Economy (In the Case of Joint Venture in Hungary, Poland and Bulgaria), Institute for Social Conflict Research, HAS \& Otto-von-Guericke University of Magdeburg, Institute of Sociology, July 1994, p. 41.

Pierre Dubois, Jenö Koltay, Csaba Makó \& Xavier Richet (eds.), Innovation et Emploi á l'Est et á l'Ouest (Les entreprises hongroises et françaises face á la modernization) (Paris, L'Harmattan, 1990).

R. Gábor, D. Tamás Horváth, J. Francois Laé \& Nicole Murard, 'Archaism et modernité-Travail Noir dans l'Artisanat et l'Artisanat dans l'Économie Secondaire', in Dubois, Koltay, Makó \& Richet (eds).

Ulrich Gehman \& Radu Stoicoviciu, 'Corporate Culture in Transition-Aspects of Organizational Behaviour and Related Socioeconomic Consequences', paper presented at the II. Chemnitz Ostforum, 'Wandel von Unternehmenskulturen in Ostdeutschland und Osteuropa', 6-9 March 1995, Chemnitz, Germany.

Bruno Grancelli, Social Change and Modernization (Lessons from Eastern Europe) (Berlin-New York, Walter de Gruyter, 1995). 
Lajos Héthy \& Csaba Makó, Patterns of Workers' Behaviour and the Business Enterprise (Budapest, Institute of Sociology, Hungarian Academy of Sciences \& Institute of Labour Research, Hungarian State Office for Wages and Labour, 1989), p. 213; (in French) Lajos Héthy \& Csaba Makó, 'Stimulants salariaux et économie planifiée', Sociologie du Travail, 1993, 1, pp. 3-44.

Lajos Héthy, Hungary's New (Emerging) Industrial Relations System (Trends and Dilemmas) (Budapest, Institute of Labour Research \& Ministry of Labour, 1992).

Lajos Héthy, From Centrally Planned to Free Market System, Industrial Relations Implications (Budapest, Institute for Labour Research, Ministry of Labour, 1993a).

Lajos Héthy, Tripartism - Its Changes and Limits in Eastern Europe (Budapest, Institute of Labour Research, Ministry of Labour, 1993b).

Lajos Héthy, 'Üzemi Tanács-Magyarországon és Európában' (Works Council in Hungary and in Europe), Munkaügyi Szemle (Labour Review), 1995a, 12, pp. 2-8.

Lajos Héthy, 'Tripartism and Wage Determination in Hungary. (Are Negotiated Wage Policies a Success or a Failure?)', International Symposium on Wages, Efficiency and Social Cohesion: Towards a Negotiated Wage Policy?, Budapest, 29 November-1 December 1995b.

Lajos Héthy, 'International Labour Standards in Central and Eastern Europe', in W. Sengenberger \& D. Campbell (eds), International Labour Standards and Economic Interdependence (Geneva, ILO, 1995c).

Albert O. Hirschman, Exit, Voice and Loyalty (Cambridge, MA, Harvard University Press, 1970). Albert O. Hirschman, Shifting Involvements (Princeton, NJ, Princeton University Press, 1982).

Akihiro Ishikawa, 'Patterns of Work Identity in the Firm and Plant: An East-West Comparison', in György Széll (ed.), Labour Relations in Transition in Eastern Europe (Berlin-New York, Walter de Gruyter, 1992), pp. 85-92.

JIL (Japan Institute of Labour), Survey on Hungarian Labour Relations 1992-1993 (The Development in the Post-Socialist Society) (the national-level survey was carried out at the end of June and early July 1992, the national sample covered 446 firms).

Csilla Kollonay \& Mária Ladó, The Situation and Rights of Trade Unions in Hungary, Comparative Project on Union Rights in an EC and Central European Perspective (Bari, Universitá di Bari, 1992).

Mária Ladó \& Ferenc Tóth Tények és kérdések az érdekegyeztetés megújitásához (Facts and Questions for the Renewal of Interest Concertation), Phare Project: Social Dialogue (Budapest, June 1995).

Teréz Laky, Munkaeröpiaci helyzetjelentés (Labour Market Review) (Budapest, Institute of Labour Research, April 1995).

Csaba Makó \& Tamás Gyekiczky, 'Sociological Aspects to Consider in an Analysis of the Problems of Labour Discipline', in Almanac of the Institute of Sociology, Hungarian Academy of Sciences, Budapest, 1988.

Csaba Makó, Transformation Patterns in the Transition to Market Economy (Background Report of the Hungarian Case) (Budapest, Institute for Social Conflict Research HAS, Project Supported by the Volkswagen Foundation, 1993).

Csaba Makó \& Ágnes Simonyi, 'Participation at Firm Level in the Transformation Process', in Grancelli (ed.), pp. 181-196.

Csaba Makó \& Péter Novoszáth, 'Employment Relations in Multinational Companies: the Hungarian Case', in J. Dittrich Eckardt, Gert Schmidt \& Richard Whitley (eds), Industrial Transformation in Europe (Process and Contexts) (London, Sage Publications, 1995), pp. 255-276.

Sylvie Mouranche, L'Experience du Tripartisme en Europe Centrale (Hongrie, République Tcheque et Pologne), Mémoire pour le DEA de Sociologie, 'Travail et Mobilités', Université de Paris X, Nanterre, September 1995, p. 83.

Alena Nesporova \& Ágnes Simonyi, Labour Market Developments in Hungary (Budapest, ILOCentral and Eastern European Team, 1994), p. 44.

Zsuzsa Orolin, 'A Cantoni Kft. munkaügyi kapesolatainak alakulása: 1990-1994' (Labour Relations in Cantoni Co. Ltd: 1990-1994), Budapest, Institute of Labour Research, 1994 (Manuscript).

Anna Pécsi, 'Hongrie-Chronique de la Préparation d'un Pacte Social', Chronique Internationale, 1994, 30, pp. 48-52.

József Poór, 'Towards the Western HRM Practices in Local Subsidiaries of MNCS in the Former Socialist Economies', 9th Workshop on Strategic Human, Resource Management-EIASM, St Gallen, 3-4 March 1994.

Ágnes Simonyi, Foglalkoztatás és munkavégzés dolgozói tulajdonban (Employment and Employees' Stock Ownership) (Budapest, Research Report-National Social Science Foundation, 1994).

Wolfgang Streeck, 'Editorial Introduction', Economic and Industrial Democracy, 3, 3, August 1988, pp. 307-308. 
Erzsébet Szalai, A civil társadalomtól a politikai társadalom felé, (Munkástanácsok, 1989-1993) (From Civil Society to the Political Society; Workers Councils: 1989-1993) (Budapest, T-Twins Kiadó, 1994).

Franz Traxler, 'Collective Bargaining: Levels and Coverage', in OECD, Employment Outlook (Paris, July 1994), pp. 167-194.

László Varga, 'Munkástanácsok Magyarországon: 1918/19-1956', in Csaba Makó \& Laszlo Neuman (eds), A munkásautonómia kiterjesztésének lehetöségei (Budapest, MTA Szociológiai Kutató Intézet, 1990).

Péter Vince, Stages of State Involvement: Dilemmas and Turning Points for Privatization in Hungary (Budapest, Kopint-Datorg, 1993).

Erzsébet Viszt, 'A termelékenység és foglalkoztatás konfliktusai a gazdasági átmenet idején Magyarországon' (Conflicts of Productivity and Employment during the economic transformation in Hungary), Közgazdasági Szemle (Economic Review), March 1994.

\section{Appendix}

TABLE A.1

Number of Business Organisations with Legal Status and their Size Structure

\begin{tabular}{lcccccc}
\hline & $\begin{array}{c}\text { Less than } \\
\text { 11 employees }\end{array}$ & $\begin{array}{c}11-20 \\
\text { employees }\end{array}$ & $\begin{array}{c}21-50 \\
\text { employees }\end{array}$ & $\begin{array}{c}51-300 \\
\text { employees }\end{array}$ & $\begin{array}{c}\text { More than } \\
\text { 300 employees }\end{array}$ & Total \\
\hline 1991 & - & 36809 & 6169 & 5372 & 2396 & 50746 \\
1992 & - & 52825 & 6970 & 5773 & 1937 & 67505 \\
1993 & 39772 & 28447 & 7637 & 6055 & 1624 & 83535 \\
1994 & 57752 & 25784 & 8041 & 6127 & 1340 & 99044 \\
1991 & - & $72.5 \%$ & $12.1 \%$ & $10.6 \%$ & $4.7 \%$ & $100.0 \%$ \\
1992 & - & $78.3 \%$ & $10.2 \%$ & $8.6 \%$ & $2.9 \%$ & $100.0 \%$ \\
1993 & $47.6 \%$ & $34.1 \%$ & $9.2 \%$ & $7.2 \%$ & $1.9 \%$ & $100.0 \%$ \\
1993 & $58.3 \%$ & $26.0 \%$ & $8.1 \%$ & $6.2 \%$ & $1.4 \%$ & $100.0 \%$ \\
\hline
\end{tabular}

Source: Laky (1995), p. 90.

TABLE A. 2

Relative Strength of Hungarian Trade Union Movement (Results of Union Elections on 21 May 1993)

\begin{tabular}{lcc}
\hline & $\begin{array}{c}\text { Percentage of votes on } \\
\text { self-management body } \\
\text { for health insurance }\end{array}$ & $\begin{array}{c}\text { Percentage of votes on } \\
\text { self-management body } \\
\text { for pension insurance }\end{array}$ \\
\hline Worker's Council & $12.8 \%$ & $10.91 \%$ \\
Bloc of Intellectual Unions & $6.79 \%$ & $6.18 \%$ \\
National Confederation of Christian Unions & $8.14 \%$ & $7.34 \%$ \\
National Confederation of Hungarian Unions & $45.22 \%$ & $50.10 \%$ \\
Autonomous Unions & $5.27 \%$ & $4.80 \%$ \\
Democratic League of Hungarian Unions & $13.13 \%$ & $10.07 \%$ \\
Cooperating Forums of the Unions & $8.39 \%$ & $10.59 \%$ \\
\hline
\end{tabular}

TABLE A. 3

Results of Works Council Elections, 1993-1995

\begin{tabular}{lcc}
\hline & $\begin{array}{c}\text { Works Council } \\
\text { elections May 1993 }\end{array}$ & $\begin{array}{c}\text { Works Council } \\
\text { elections May 1995 }\end{array}$ \\
\hline ÁSOK (Autonomous Trade Unions' Confederation) & $18.07 \%$ & $20.37 \%$ \\
ÉSZT (Intellectual Workers' Trade Union Association) & $0.66 \%$ & $0.80 \%$ \\
Liga (Democratic League of Independent Trade Unions) & $5.66 \%$ & $6.40 \%$ \\
MOSZ (National Alliance of Workers Councils) & $2.20 \%$ & $2.47 \%$ \\
MSZOSZ (National Association of the Hungarian & $71.67 \%$ & $66.56 \%$ \\
$\quad$ Trade Unions) & $0.02 \%$ & $0.07 \%$ \\
SZEF (Trade Unions' Cooperation Forum) & $1.22 \%$ & $3.36 \%$ \\
Others (independent candidates) & & \\
\hline
\end{tabular}

Source: MSZOSZ documents. 


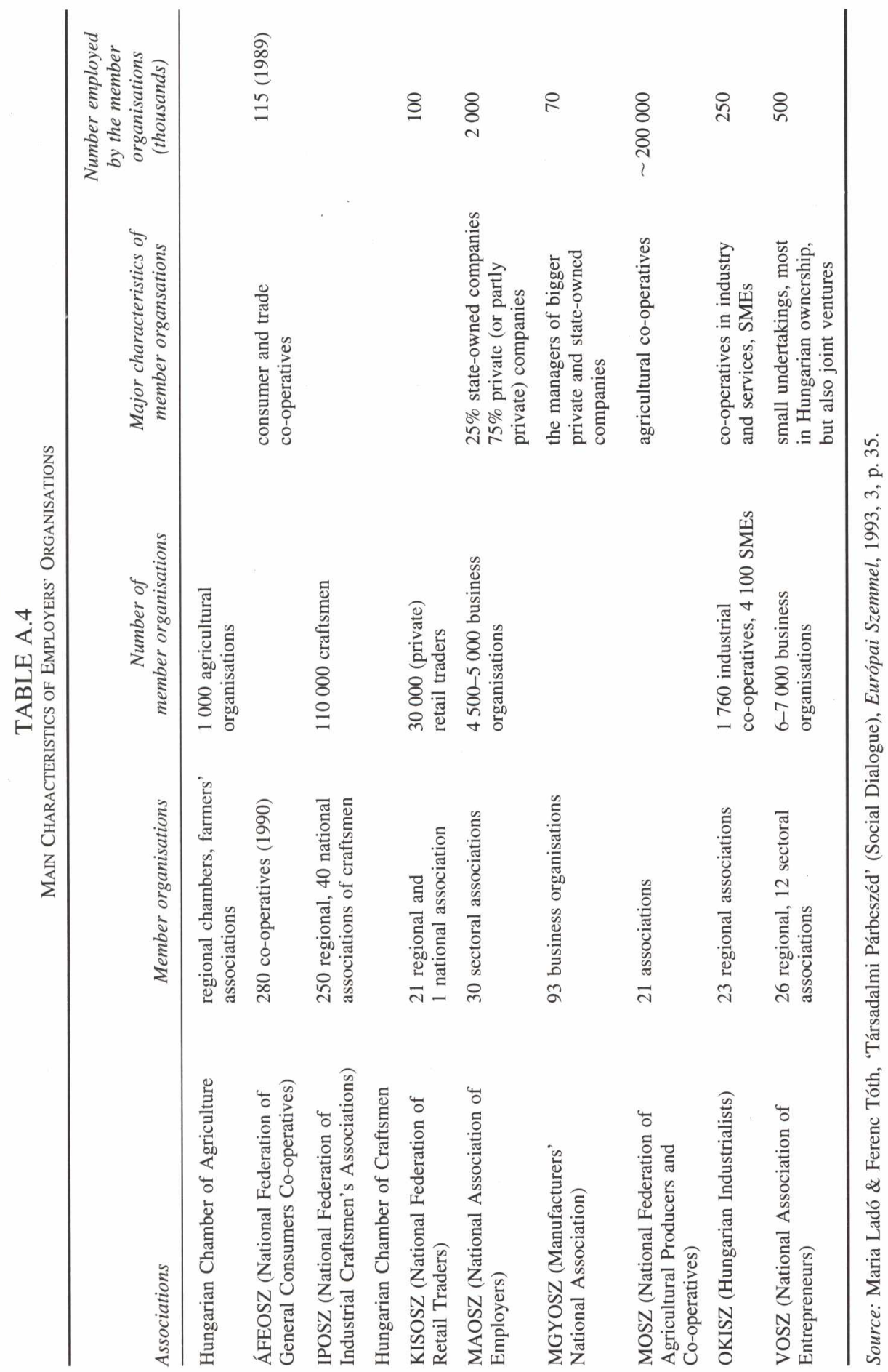


TABLE A.5

AtTItUdes of Foreign EMPlOYers Toward Trade Unions

\begin{tabular}{|c|c|c|}
\hline Name of company & $\begin{array}{l}\text { Nationality of } \\
\text { foreign owner }\end{array}$ & $\begin{array}{c}\text { Number in the } \\
\text { workforce }\end{array}$ \\
\hline \multicolumn{3}{|l|}{ Positive attitude } \\
\hline Ganz Ansaldó & Italian & 1500 \\
\hline Elektrolux-Lehel & Swedish & 2500 \\
\hline Ganz Mérögyár Ltd & French & $600-700$ \\
\hline ABB Láng & Swiss & 600 \\
\hline Packard Elektrik & German & 600 \\
\hline Lang Gépgyártó Ltd & German & $200-300$ \\
\hline \multicolumn{3}{|l|}{ Negative attitude } \\
\hline GB Ganz Tüzeléstechnikai Ltd & Italian & 50 \\
\hline Comasec Respirator & French & 170 \\
\hline Knorr Bremse & German & 250 \\
\hline General Motors Hungary & US & 500 \\
\hline Magyar Suzuki Co. & Japanese & 500 \\
\hline Celba Ltd & Austrian & 100 \\
\hline Orosházi Mezögép & US & $600-700$ \\
\hline \multicolumn{3}{|l|}{ Indifferent } \\
\hline Siemens-Terta Ltd & Austrian & 700 \\
\hline Schmidt und Bender MOM & German & $200-300$ \\
\hline Hungary Optikai Ltd & & \\
\hline Magnetek Hungary & US & $150-200$ \\
\hline Villamosgépgyár Ltd & & \\
\hline Kromberg és Schubert & Austrian & 100 \\
\hline BRG ELSA Ltd & Dutch & 100 \\
\hline
\end{tabular}

Note: The share of the foreign ownership in each case is dominant. Source: Vasas Trade Union Federation, January 1994.

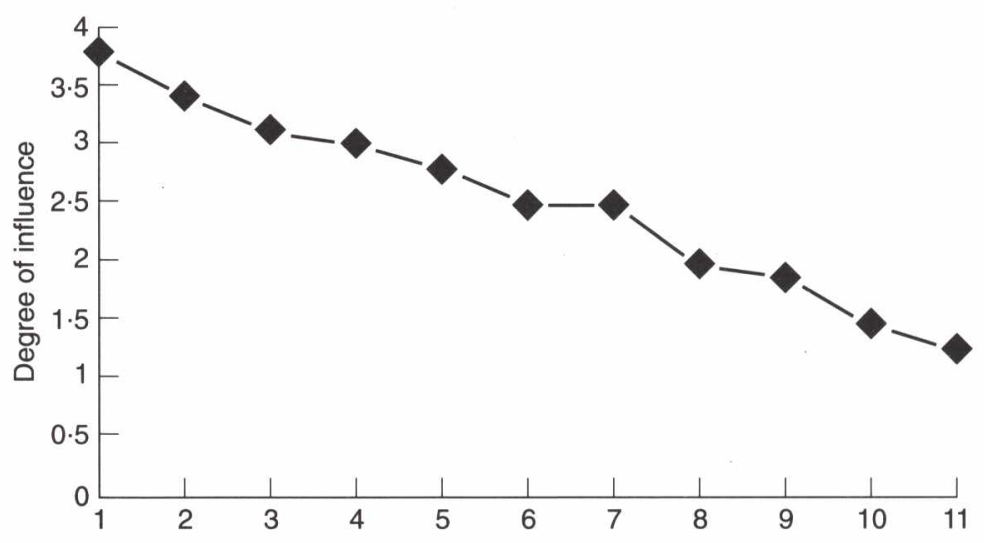

FigURE A.1. Influence of Trade Unions Within the Firm

Note: Weighted average value calculated on five-point scale.

$1=$ social welfare; 2 = wages; 3 =dismissal; $4=$ organisation of working time; $5=$ working time; $6=$ closing plants; $7=$ performance standard (set up) $; 8=$ establishment of a joint venture $; 9=$ recruitment; $10=$ introduction of new technology; $11=$ elaboration of production plans.

Source: The Japan Institute of Labour (JIL) Survey: Hungarian Labour Relations (The Development in the Post-Socialist Society), 1992. 
TABLE A.6

LeVels ANd Forms of Collective Bargaining (DeCember 1994)

\begin{tabular}{llc}
\hline & & Employment \\
Levels & General economic and social & relations (C.B. in \\
targets (C.B. in broad sense) & narrow sense) \\
\hline
\end{tabular}

Economy-wide (macro)

National Council for Reconcilation of Interests (CRI) - (plenary and committee sessions)

Sector-level

Council for Interest Reconciliation in Public Sector (KIÉT), Forum of Interest Reconciliation for Civil Servants (KÉF)

Meso or branch-level

Branch level forums of interest reconciliation:

- Council of Interest Reconciliation in Ministry of Interior

- Council of Interest Reconciliation in Ministry of Defence

- Council of Interest Reconciliation in Ministry of Industry and Trade, etc.

- Labour Relations Councils at county level

Firm/establishment level CRI at work places

C.B. etc. firm-level

Source: Lado \& Tóth (1995), p. 3.

TABLE A.7

Statutory Minimum Wage in Hungary, 1988-1995

\begin{tabular}{lcc}
\hline & Monthly (in HUF) & Hourly (in HUF) \\
\hline 1 January 1988 & 3000 & 16.50 \\
1 March 1989 & 3700 & 20.50 \\
1 October 1989 & 4000 & 22.50 \\
1 February 1990 & 4800 & 26.50 \\
1 September 1990 & 5600 & 31.00 \\
1 December 1990 & 5800 & 32.00 \\
1 April 1991 & 7000 & 38.50 \\
1 January 1992 & 8000 & 44.00 \\
1 February 1993 & 9000 & 52.00 \\
1 February 1994 & 10500 & 60.50 \\
1 February 1995 & 12200 & 71.00 \\
\hline
\end{tabular}

Source: Héthy (1995), p. 10.

\section{1 icber $1518 \quad 19.500$ \\ 1511 22.500}

